\title{
One Day One Hadith with Online Media: Challenges and Opportunities
}

\author{
$1^{\text {st }}$ Limmatus Sauda ${ }^{1}$ \\ \{limmah.sauda@gmail.com ${ }^{1}$ \} \\ Institut Pesantren KH. Abdul Chalim, Mojokerto, Indonesia ${ }^{1}$
}

\begin{abstract}
Fathul Bari, an Islamic scholar from Indonesia, takes the benefits of the advancement of technology and social media to share knowledge and information. $\mathrm{He}$ initiates the program of 'one day one hadith', an online program of studying hadith about public-related issues and posting the discussion on the WhatsApp group chat. Presenting concise, dense and reliable discussions, Fathul Bari has been successfully popularised the hadith not only in Indonesia but also across countries, as well as attracted public interest in involving in this program. This paper, therefore, aims at discussing the challenges and opportunities of studying hadith in millennial era.
\end{abstract}

Keywords: Hadith; challenges; opportunities

\section{Introduction}

Alfatih Suryadilaga [1] stated that there has been a growing number of the study of Hadith with the use of technology, ranging from software applications, publishing online journals articles, to programs on television and youtube. The programs commonly include the study of the authenticity of hadith, the study of books of Hadith and the study of understanding the hadith. This phenomenon occurs in response to technological advances. Thus, this adaptation will go hand in hand as the creativity and innovation of technology bring plausible possibilities to the innovation in the study of hadith as what the writer expects to discuss in this paper.

Since 2016, digital hadith studies have begun to take advantage of other online applications namely Whatsapp Messenger, an online chat app that is compatible with several types of smartphones. The program is called One Day One Hadith (ODOH). In the beginning, it was just an act of posting

One hadith in a WhatsApp group chat of students and alumni of pesantren an-Nur $2 \mathrm{Al}-$ Murtadlo Malang. However, it eventually has become a daily routine. The ODOH program, which is led by Fathul Bari who is also a pesantren principle, is meant to facilitate members in knowing and studying the hadith. This objective is then supported by the choosing Whatsapp Messenger as a medium of communication.

Learning method using digital mode of communication as previously mentioned is considered as sufficient. As evident, many WhatsApp users are interested in reading and even eager to learn more every day. In addition, the theme of discussion has been selected from everyday issues experienced by the community. Arguably, in this way, Gus Fathul, the 
nickname of Fathul Bari, succeeded in popularising the hadith which has been less popular compared to the study of the Qur'an and tafsir.

This article attempts to trace back the One Day One Hadith program from its early history, its review system, the reader's response, its position and role in the development of the study of hadith in Indonesia as well as the opportunities and challenges of its implementation.

\section{Review of Related Literature}

Hadith studies are able to adapt to technological developments in the millennial era. One Day One Hadith phenomenon include in it. Therefore, the previous literature that we brought in this study is the writing with the theme of hadith studies in the millennial era.

Since 2014, there are at least four research that carry the theme of hadith studies, millennial eras and also technological developments. Such as:

Kajian Hadis di Era Global by Muhammad Alfatih Suryadilaga [1] presents a variety of hadith studies in present-day, from the type of media which is used, books in pdf, software application of hadith studies, online journals, television program of hadith studies to the study of hadith on youtube. However, this paper still only explain, not analyze. The study of hadith by online media like WA messenger has not been mentioned at all here.

Application of Modern Technology in the Study of Hadith and Its Sciences: A Case Study, a collection of research results compiled by Chowdhury Mesbahul Hoque and a team [2]. Based on the abstract, it is known that this study discusses the use of technology in the study of hadith. Here it says that using innovative technology makes studying hadith much simpler and enjoyable. For example, searching the source of Hadith and determining their authenticity have become more easily accessible. Even so, not all innovative technology is discussed, apps and websites for studying software Hadith are part of priority technology that is prioritized.

The Profundity Of Hadith Materials On 'Islam Itu Indah" On Trans Tv by Nurun Najwah [3]. This study discusses the hadith that are often displayed in a program television, 'Islam Itu Indah'. The issue of authenticity, transmission and understanding of the hadith is still an highlighted part. Indirectly, this study concludes that the validation of hadith on a television program is still lacking, far from the minimum standard of Hadith transmission.

User Awareness On The Authenticity Of Hadith In The Internet: A Case Study by Nurul Nazaria Mohd Zaidi and Mesbahul Hoque Chowdhury [3]. This study provides insightful information about the usage of the Internet and user awareness on Hadith among Muslim students. Although Internet have been used by almost all of the participants in the study, they have collectively aware that certain criteria needed to be applied to ensure the Hadith and its information acquired is accurate and reliable. Among the important criteria need to be considered by the users about knowledge of Hadith on Internet are: the need to know the sources of information used, the need to verify the content of Hadith, the need to justify the authenticity of Hadith, the authenticity of hadith can be referred to or consulted with the more knowledgeable people in the field of Hadith. This study should benefit users of the Internet in the assessment of awareness on authenticity of Hadith on the Internet. With some criteria resulted in this study, awareness values can be increased and the risk of using false information can be reduced.

\section{Methodology}


The present study is conducted by descriptive qualitative method. As proposed by Donald Ary [4], this method is aiming to explain, illustrate, and analyze the phenomenon, One Day One Hadith (trending strategy in teaching hadith nowadays). Phenomenology method is also used as an approach in this research, to explore the benefits of this program, as well as the drawbacks.

Subjects of this study include all participants of the program, ranging from the author of hadith study (a.k.a Fathu al-Bari), members of ALVERS group, and common people receiving the hadith posts.

Some interviews used to collect the data. interview with Fathul Bari as faounder of $O D O H$, other interview are with students, alumni of An-Nur 2 and participants of One Day One Hadith. Data is collected based on farious perspective, founder perspective, and also readers'perspective.

Analysis techniques used in this research was the analysis of qualitative data following the concept of Miles and Huberman [5]. Activities in data analysis were data reduction, data display, and drawing conclusion, these steps should be conducted systematically.

\section{Result and Discussion}

\subsection{The Beginning of One Day One Hadith: From online world towards the real World}

It is An-Nur 2 Al-Murtadlo Islamic boarding school in Bululawang Malang, East Java, Indonesia who has a significant role in the establishment of 'One Day One Hadith' (a.k.a. 'ODOH'). Following the development of the digital era, the members of this pesantren (Islamic boarding school) including principles, students, teachers, employees and alumni, create Whatsapp group chatting named ALVERS, the abbreviation of Al-Murtadlo Lovers. As the manager is none other than their own pesantren's principle, Fathul Bari. The initial goal of this online group is as a medium to keep in touch among fellows, students and alumni of AnNur 2. However, over time, many of the members of this online group chatting expect Fathul Bari, or it is commonly called as Gus Fathul to post one hadith every day as a reference to discuss current religious issues or problems in the society. This daily hadith online post inspires the creation of more formal and focused discussion as Fathul Bari said

"this is the beginning of One day one hadith"e.

In order to keep motivated and maintain the continuity of this activity, the adherents of this virtual group chatting have created new slogan namely 'make your mobile phone as the source of knowledge and goodness ${ }^{e c}$. Interestingly, all members have agreed on Gus Fathul as the person who posted the hadith. Thus, the source of the hadith comes from one and reliable person. Initially, the study of hadith posted in the form of one selected topical hadith and its translation only. However, it then has developed to be an article which is longer in both of word accounts and the content involving a discussion of the hadith as a reference to the current issues in the society.

Similarly, the development also can be seen in the type and the number of the online group chatting members. In the first days, the group seemed to appear to be an exclusive group consisting of teachers, students, employees and alumni of the pesantren only. However, it then disseminates embracing publics who are interested in joining the group. Many of the members share the post with other groups, and the other group also forward it to their relatives and friends and so on. This is how the dissemination occurs by itself. However, the shared link tab available in the Whatsapp helps the spreading reaches even broader communities. 
The persistence of ODOH attracted many public interests. It can be seen from the increase of WhatsApp group number which until recently there have been nine groups available. Seven out of the nine groups are aimed at particularly discussing the study of hadith, questioning and answering (Q\&A) related religious issues, and others. The commitment to focusing on the study has been very seriously demonstrated by the group's managers, especially from the pesantren's own principles. There are some rules that must be obeyed and implemented by people who want to join the seven groups: group members are not allowed to post unrelated and inappropriate posts such as posts containing political issues, Wahhabism (the extremist group of Muslims) and Shiah (the opposition doctrine of Islam against Sunni), advertisements and hoaxes.

However, the principles of the pesantren do consider and accommodate the need of its members to develop and explore their interests and benefits other than studying the hadith. Therefore, the rest of two groups, namely free Alvers and ladies Alvers which is specifically provided for females, have been dedicated to facilitating this needs. Each group has 257 members, meaning there are already about two thousand members who joined in ODOH. Group members includepeople from Java, Madura, Sumatera, Kalimantan, and Indonesian diaspora who live across countries such as Yemen, Malaysia, Thailand and other South East Asian countries.

In its progress, ODOH program also launch the official website, http://www.onedayonehadith.net/. This further reinforces the effectiveness of social media in disseminating knowledge and information.

Nevertheless, there are some concerns conveyed by Alvers and ODOH members regarding $\mathrm{ODOH}$ programs in social media. First, social media are dynamic. They keep changing and upgrading. Todays, social media will be shifted with more sophisticated similar apps. They might be abandoned by users and eventually even disappear. Second, not everyone has considerable time to go online. Third, WhatsApp may be too small for some people to write and post articles and they are often overlapped by other more recent posts and conversations. For this reason, Alvers suggested that ODOH's postings were published into a book.

In addition, the accuracy of the source is also a matter of concern, the posts shared in social media must be ready to be plagiarism at any time. on the contrary, other people's posts are made in the same name as $\mathrm{ODOH}$ must also be allerted.

Fathul Bari have been writing four One Day One Hadith book series with different themes. They are Indahnya hidup bersama Rasulullah (Beautiful Living with the Messenger of Allah); Motivasi bahagia dari Rasulullah (Motivation of happiness from the Prophet); Taman Indah Musthafa" (Beautiful Garden of Mustafa); and Tafakur Zaman Now(Reflection in millennial era).

The language and the structure of the discussion or the article are made to be less sophisticated so as it is understandable for all readers. Fathul Bari [6] said that the discussions start from daily human affairs such as the way of shake hand, emotional therapy, the views of Islam on matchmaker, and others, to be more specific involving the discussion of unique traditions among Muslims such as wiping the head of orphans in the month of Muharram (the first month in Islamic calendar), and the unlucky days of Shafar (the second month in Islamic calendar). The discussion also includes more general themes such as the study of the celebration and the reflection of the new year, mayday in Indonesia, April mop, and so on.

The rationale of this the explanation is to make the discussion is understandable by all member regardless of their status and academic level. It also aims at providing relaxing 
nuance of learning and reading while they are discussing heavy matters figh (Islamic jurisprudence) in relevance to contemporary issues.

Therefore, the articles of One Day One Hadith are concise, dense, and reliable. They are concise because they are designed to be read at one go; They are dense because the explanation is straightforward to the core of the problems, and they are reliable because they refer to the valid and reliable sources.

The sources of the hadith discussed by Fathul Bari is kutub as-sittah (six reliable hadith books) and several other syarh al- hadith (explanation hadith references) which also reliable.

\subsection{One Day One Hadith: Introducing and popularising the Hadith in ' $\mathrm{Z}$ Generation' \\ era}

al-Ramahurmuzi [7], the author of the first book of ulumul hadith started the first chapter of his book discussing al-Muhaddis al-Fasil Bayn ar-Rawi wa al- Wa'i or the virtue of the person who transmits the hadith of the Prophet. The discussion also included the explanation of some virtues of people who learn and teach the hadith. For example, they can receive a direct blessing from the chosen prophet Mohammad (may peace be upon him); also It is claimed that their faces will radiate happiness. Alvers consider this idea as motivation on which ODOH programs is aimed to carry.

Although $\mathrm{ODOH}$ is not the only program that carries this spirit, however, the ODOH program has contributed to providing different nuances in the study of hadith, especially in the millennial era. Fatai Owolabi Jamiu [8] said that The use of innovative technology by teachers will give the students the opportunities of becoming a part of the knowledge age and at the same time increase skills imparted to the young ones in an increasingly complex world.

After studying the hadiths in a traditional way for prolonged periods, this $\mathrm{ODOH}$ program made a breakthrough by studying the hadiths in a more modern way by utilising the media screen make it more interactive. Gus Fathul states that the initial and ultimate goal of this program is none other than to make his writings to be useful for everyone. A simple yet very noble goal as the program has positive influences for its members.

Using the concise, dense and reliable system, every post, the One Day One Hadith consists of: first, the theme of the hadith. The theme of the hadith raised adapts to the existing tranding topic in society. Second, matan hadith (contents of hadith) without complete sanad. Matan hadith is only included in the first narration, but still says the mukharij. this indicates that when there are people who want to judge the sanad, he can use the first narrator and the mukharij. Third, the translation of hadith. This is the first step in giving an explanation of the hadith. Then the fourth is an explanation. In this part, Fathul Bari mention other hadiths are related with theme, also other information from many scholars.

In accordance with the delivery system, concise, dense and reliable, Fathul Bari tries to study the hadith as briefly and concisely as possible, but remains accurate, following the basic rules of transmission of basic hadith. As seen in his post, In his narration, Fathul Bari included rawi, although only one person, called the complete reference source of the book with the hadith number quoted. This is very useful for critical data sanad. As for matan, alluding to other traditions relating to the theme of hadith is one of the steps in the criticism of Islam, as well as the inclusion of the statement of the ulama.

Thus means $O D O H$ educates the public about the hadith in a very simple way. From the beginning this was the goal of the ODOH program.

One day One Hadith which was initiated by Fathul Bari was different from the same study that was in the Darus Sunnah (Hadith Study Intitute that establshed by KH. Ali Mustafa Ya'qub in Jakarta). This difference can be seen from several points of the post. The Fathul 
bari's version contains five points, as described above. Whereas the Darus Sunnah's version does not include no other hadith are relating to the core hadith theme. Besides that the explanation is still shorter than Fathul Bari's version.

The $O D O H$ program also offers some benefits in the study of hadith. Firstly, it helps to manage the time for discussion efficiently and to gain more readers or members. The use of WhatsApp certainly helps ODOH program to reach more numerous and diverse participants or readers than similar but offline programs. If 257 members of each group of Alvers group chatting read and forward the posts of the hadith to another group which also has about a similar number of members then immediately can multiply the number of people who study hadith.

Secondly, the themes and topics of discussion of the hadith are related to daily life issues which are familiar to the communities, as well as the presentation of the hadith narrated in concise, dense and accurate ways makes the program more accessible and attractive for everyone to learn. As the evidence, the member of Alvers group chatting keeps growing enriching people from other countries such as Malaysia, Yemen and Thailand. Furthermore, the effort of managers of $\mathrm{ODOH}$ program to persistently provide accurate information from reliable sources aims at minimising hoaxes which often easily shared through social media.

Third, since the source of the citation and the explanation of the hadiths come from a teacher that widely acceptable to be reliable and professional, namely Fathul Bari, the ODOH offers accessibility for further questions and discussions. In fact, ODOH program allows every member to access Fathul Bari through personal contact for confirmations and or questions.

Fourth, ODOH program can effectively popularise the study of hadith in the ,Z generation' era. It could generally be known that „Z generation' era is the era where people are equipped with the use of technology to make their life easier even since the first days of their life. We are now living in those times. Inevitably, we must adapt to it but maintain our role as the subject that operates the technology and not the opposite. ODOH does adapt to this era by their program to posts the hadith and its discussion through a digital mode of communication as a daily routine. Since the establishment of ODOH program, many of Alvers member become more positive toward the use of WhatsApp messenger. More importantly, subsequently they can learn and contemplate the value of the hadith the posted in WhatsApp group chatting every day.

\subsection{One Day One Hadith: The Development of the Study of Hadith in Indonesia}

Studies of Hadith in Indonesia are relatively new compared to other religion-based studies. Berg -as cited in Danarta [9] states that in 1886 any pesantren in Indonesia did not mention the Hadith as one of the subjects taught in the school systems. However, Bruinessen -still from Danarta citation- further clarifies that students have learnt hadith in an integrated syllabus. In other words, they did not learn hadith as a separated subject, but it is often found to be included and learned in all other fields of studies. Mujamil Qomar [10] stated In the 20th century, books of hadiths started to be sufficiently recognised in pesantren.

Initially, the teachings of Hadith and must alah\} al-hadith took place and included in the curriculum of the learning and teaching in Pesantren [11]. Agung Danarta [9] said that there are some Pesantren in Indonesia who are well-known for their hadith teaching, they are Pesantren Tebuireng, which is known as the "Pondok Hadiths" under the supervision of KH. Hasyim Asy'ari (1875-1947 AD), Pesantren of Tambak Beras managed and controlled by KH. A. Wahab Hasbullah (1888-1971 AD), Pesantren of Denanyar supervised by KH. Bisri Syansuri (1886-1980 AD) and others. M. Habib Chirzin (1995) [14]. 
In the 2000s, there were two well-known Indonesian figures in the field of Hadith studies, namely Ali Mustafa Ya'qub with his popular program Darus Sunnah and Lutfi Fathullah with his famous program „study Center of Hadith“e. Those two figures have been adapted the hadiths into the Indonesian context, as well as using Bahasa Indonesia as its instructional language. However, although relatively new, it might not be overwhelming to award Fathul Bari with his ODOH program, as a scholar whose expertise is in studying hadith as these two figures. Because he also studies and examines the hadiths concerning the Indonesian context, especially regarding reviewing the meaning and understanding of the hadith.

Compared to hermeneutics studies in Indonesia, the study of hadith is relatively rare, including the lack of the experts and the works of hadith. The series of „one day one hadith" by Fathul Bari, therefore, enriches the study of Hadith in Indonesia. Not only because the author himself from is Indonesian but also because the discussion and the critics contain Indonesian values such as the discussion of halal and haram (forbidden) food. The explanation of hadith related to food and nutrition day was delivered on $25^{\text {th }}$ of January. In his writing, Gus Fathul narrated the story of kyai Hamid, one of respected and influential Muslim figure and scholar from Pasuruan, Indonesia. It is told that Kyai Hamid once accepted a gift from the guest which turned out to be a sum of money. However, he dampened the money, and it disappeared. The only things left is the stinky smell from the water where the money sank.

Futher, Gus Fathul [6] explains that the lesson learned from this story is that ones must always be aware of the source of their wealth and their possession. There are more other stories related to contextual values about explaining the meaning and understanding of the hadith in this series of the book of ODOH.

\section{Conclusion}

One Day One Hadith (ODOH) program is an online program of studying hadith about public-related issues and posting the discussion on the WhatsApp group chat. It is explained by concise, dense and reliable system. However, over time, many of the members of this online group chatting expect Fathul Bari suggested that ODOH's postings were published into a book. This shows the positive and negative side of online program of studying hadith. As an early promotion, using online media, especially WhatsApp group chat to introducing and grounding hadith in the community is very effective. As in other things, such as writing storage will be very constrained, because it can be closed with other messages or even deleted. In this way, it is positively revealed that $\mathrm{ODOH}$ is a freshly-used strategy to introduce and teach hadith in this era. This study also points out the interactive situation between teachers and learners through technology. ODOH make people comprehend that they can gain a lot from their gadgets and Android apps, especially WhatsApp. Consequently, this will eliminate the negatively growing- perspective towards the media as hoax-spreader. Meanwhile, the drawbacks of the program is the minimum concerns of the participants towards the $\mathrm{ODOH}$ posts, often being skipped-unread, and the safety of posts documentation along with the smartphone memory and belonging. Henceforth, the periodic publication of $\mathrm{ODOH}$ in a serial book is really needed.

Thus, One Day One Hadith program has demonstrated the opportunities and challenges in the same time of the development of technology in hadis studies. 


\section{References}

[1] Suryadilaga M A 2014 Kajian Hadis di Era Global Esensia 15

[2] Hoque C M, Rab M A A, Said W M, Ghazali N M, Mohamed Y and Toure A K 2017 Application of Modern Technology in the Study of Hadith and Its Sciences: A Case Study Adv. Sci. Lett. 23

[3] Zaidi N N M and Chowdhury M H 2017 User Awareness On The Authenticity of Hadith In The Internet: A Case Study 2nd INHAD International Muzakarah \& Mu'tamar on Hadith

[4] Ary D, Jacobs L C, Sorensen C and Asghar Razavieh 2010 Introduction to Research in Education (Wadswort: Cengage Learning)

[5] Miles M B and Huberman A M 2014 Qualitative Data Analysis (United States of America: Sage Publications)

[6] Bari F 2016 Indahnya Hidup Bersama Rasulullah (Malang: Pustaka An-Nur Al-Murtadlo)

[7] Al-Ramahurmuzi al-H bin 'Abd al-R 1771 al-Muhaddis al-Fasil Bayn ar-Rawi wa al- Wa'i (Beirut: Dar al-Fikr)

[8] Jamiu F O 2016 Enhancing Arabic And Islamic Studies Education In Yorubaland Through Innovation And Technology the 2nd Interdisciplinary Conference of TASUED-UCC

[9] Danarta A 2004 Perkembangan pemikiran Hadis di Indonesia (Sebuah Upaya Pemetaan Esensia 5

[10] Qomar M Menuju Demokratisasi Institusi (Jakarta: Erlangga)

[11] Bruinessen M Van 1994 NU, Tradisi, Relasi-Relasi Kuasa, Pencarian Wacana Baru, trans. Farid Wajidi (Yogyakarta: LKiS) 